\title{
SELECTIVE FUNCTIONALIZATION OF CALIX[4]ARENES AT THE UPPER RIM
}

\author{
J.-D. van Loon ${ }^{a}$, A. Arduini ${ }^{b}$, W. Verboom ${ }^{a}$, R. Ungaro ${ }^{b}$, G.J. van Hummel ${ }^{\text {a }}$, S. Harkema ${ }^{\text {a }}$, D.N. Reinhoudt ${ }^{* a}$ \\ Laboratories of Organic Chemistry and Chemical Physics ${ }^{a}$, University of Twente, 7500 AE Enschede, The \\ Netherlands and the Institute of Organic Chemistry ${ }^{b}$, University of Parma, 43100 Parma, Italy
}

Abstract. Methods are described for the selective diametrical functionalization of calix[4]arenes at the upper rim by transfer of functionality and selective substitutions at the para positions of the phenol rings. The crystal structure of 26,28-dimethoxy-11,23-dinitrocalix[4]arene is described.

Calix[4]arenes ${ }^{1}$ are able to form host-guest complexes in the solid state ${ }^{2}$ as well as in solution ${ }^{3}$. Most work has been directed to the complexation of cations in the 'polyoxygen' cavity (lower rim) ${ }^{4}$. Recently, we have used 26,28-dimethoxy-p-tert-butylcalix[4]arene as a building block for the synthesis of ligands (calixspherands) that form kinetically stable complexes with alkali salts ${ }^{5}$. There are only a few examples of complexes with guests complexed in the upper rim cavity ${ }^{2,3}$. The reason for this is probably the lack of appropriate functionality at the upper rim. Although several routes have been developed to introduce functional groups at the para positions of the phenol rings ${ }^{6}$, they all lead to tetrasubstituted calix[4]arenes, having the same substituent at all the para positions ${ }^{7}$. The elegant stepwise routes developed by Böhmer et al. ${ }^{8}$ give access to unsymmetrically substituted calix [4]arenes, but the method is quite laborious and requires strongly acidic conditions in the ring closure step.

Our objective was to develop facile routes for the selective functionalization of the upper $\mathrm{rm}$ by the introduction of two functional groups. The methodologies are based on the transformation of selectively dialkylated calix[4]arenes (vide infra) either by transfer of functionality from the lower rim to the upper rim or by selective substitution reactions at different para positions of the phenol rings.

Because the literature procedure ${ }^{9}$ for the selective methylation of $p$-tert-butylcalix[4]arene with diazomethane is not suitable for larger scale synthesis we developed an alternative and more general route for the diametrical alkylation. When calix[4]arene 1a was reacted with two equivalents of methyl tosylate, allyl bromide or benzyl bromide in the presence of one equivalent of $\mathrm{K}_{2} \mathrm{CO}_{3}$ in refluxing acetonitrile, almost quantitative yields of the exclusively diametrically substituted calix[4]arenes 2 a-c were isolated ${ }^{10,11}$. The ${ }^{1} \mathrm{H}$ NMR spectra show a typical AB pattern for the methylene bridge protons at $\delta 4.3$ and $3.3(J=13 \mathrm{~Hz})$, indicating that 2a-d exist in the cone conformation. We suppose that two factors might influence the regio- and conformational selectivity. Firstly, under the reaction conditions described above the monoalkylated calixarene will be deprotonated and the negative charge will be mainly located at the oxygen atom located diametrically to the alkoxy group because of the two stabilizing hydrogen bonds. This keeps the molecule in the cone conformation. Subsequent alkylation will occur at this oxygen atom opposite to the alkoxy group. Secondly, steric effects may also play an important role and consequently alkylation of the monosubstituted species will take place from the less hindered site ${ }^{12}$.

The first approach for the selective functionalization at the upper rim comprises the transfer of functionality from the lower rim to the upper rim. Reaction of 26,28-dimethoxycalix[4]arene 2a with allyl bromide and $\mathrm{NaH}$ 

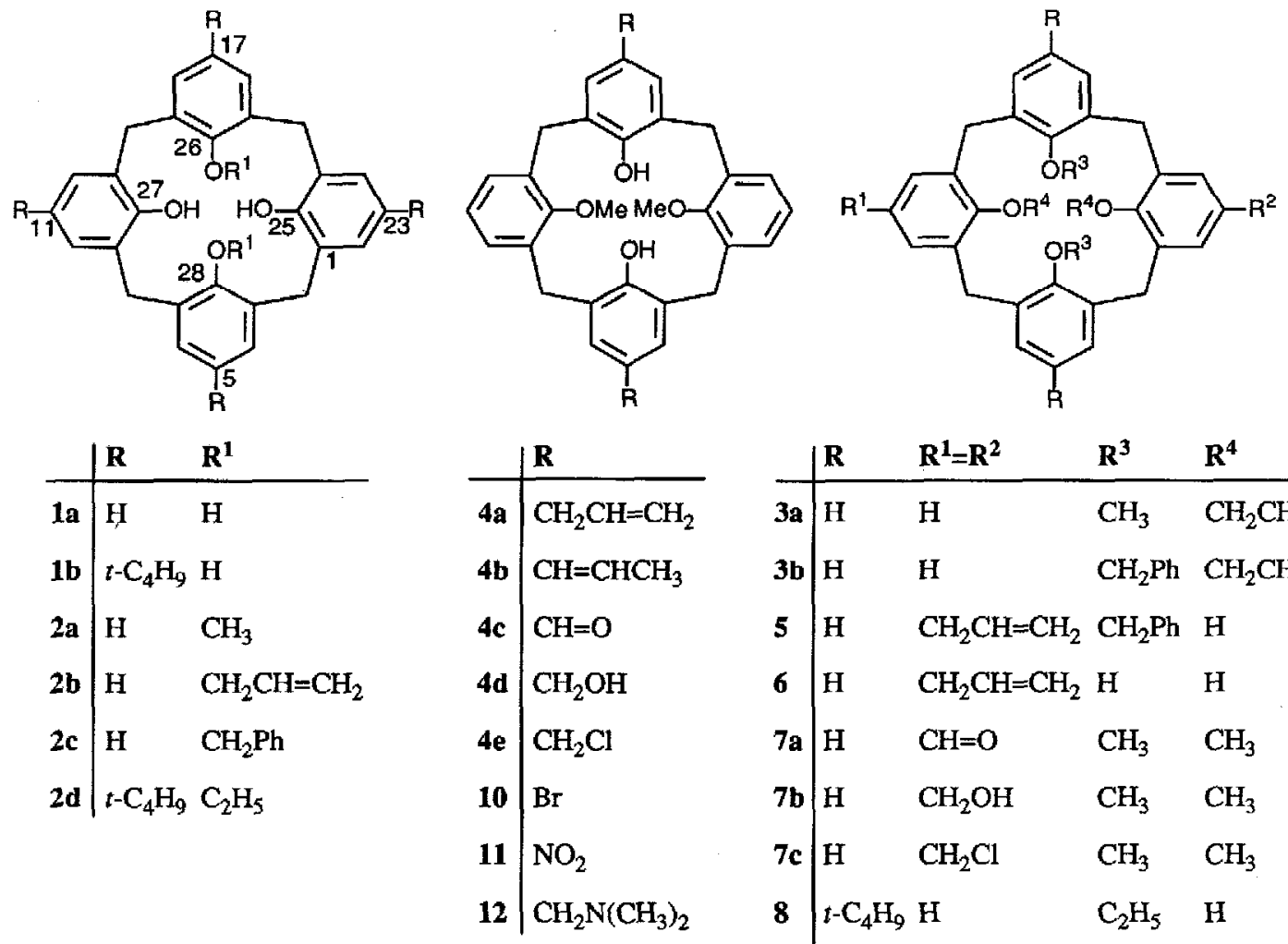

\begin{tabular}{l|llll} 
& $\mathbf{R}$ & $\mathbf{R}^{1}=\mathbf{R}^{2}$ & $\mathbf{R}^{3}$ & $\mathbf{R}^{4}$ \\
\hline $3 a$ & $\mathrm{H}$ & $\mathrm{H}$ & $\mathrm{CH}_{3}$ & $\mathrm{CH}_{2} \mathrm{CH}=\mathrm{CH}_{2}$ \\
$\mathbf{3 b}$ & $\mathrm{H}$ & $\mathrm{H}$ & $\mathrm{CH}_{2} \mathrm{Ph}$ & $\mathrm{CH}_{2} \mathrm{CH}=\mathrm{CH}_{2}$ \\
$\mathbf{5}$ & $\mathrm{H}$ & $\mathrm{CH}_{2} \mathrm{CH}=\mathrm{CH}_{2}$ & $\mathrm{CH}_{2} \mathrm{Ph}$ & $\mathrm{H}$ \\
$\mathbf{6}$ & $\mathrm{H}$ & $\mathrm{CH}_{2} \mathrm{CH}=\mathrm{CH}_{2}$ & $\mathrm{H}$ & $\mathrm{H}$ \\
$7 \mathbf{a}$ & $\mathrm{H}$ & $\mathrm{CH}=\mathrm{O}$ & $\mathrm{CH}_{3}$ & $\mathrm{CH}_{3}$ \\
$7 \mathbf{b}$ & $\mathrm{H}$ & $\mathrm{CH}_{2} \mathrm{OH}$ & $\mathrm{CH}_{3}$ & $\mathrm{CH}_{3}$ \\
$7 \mathbf{c}$ & $\mathrm{H}$ & $\mathrm{CH}_{2} \mathrm{Cl}$ & $\mathrm{CH}_{3}$ & $\mathrm{CH}_{3}$ \\
$\mathbf{8}$ & $t-\mathrm{C}_{4} \mathrm{H}_{9} \mathrm{H}$ & $\mathrm{C}_{2} \mathrm{H}_{5}$ & $\mathrm{H}$ \\
$9 \mathbf{9 a}$ & $t-\mathrm{C}_{4} \mathrm{H}_{9}$ & $a)$ & $\mathrm{C}_{2} \mathrm{H}_{5}$ & $\mathrm{H}$ \\
9b & $t-\mathrm{C}_{4} \mathrm{H}_{9} \mathrm{CH}_{2} \mathrm{~N}\left(\mathrm{CH}_{3}\right)_{2}$ & $\mathrm{C}_{2} \mathrm{H}_{5}$ & $\mathrm{H}$ \\
a) & $\mathrm{R}^{1}=\mathrm{H}_{2} \mathrm{R}^{2}=\mathrm{CH}_{2} \mathrm{~N}\left(\mathrm{CH}_{3}\right)_{2}$ &
\end{tabular}

in refluxing THF afforded the 25,27-diallyl-26,28-dimethyl ether $3 \mathrm{a}$ in $91 \%$ yield (mp $157-158{ }^{\circ} \mathrm{C}$ ). Claisen rearrangement of $3 a$ in refluxing $\mathrm{N}, \mathrm{N}$-dimethylaniline afforded $4 \mathrm{a}\left(\mathrm{mp} 265^{\circ} \mathrm{C}\right.$ decomp.) and subsequent isomerization of the double bonds in $4 \mathbf{a}$ with KOtBu in refluxing THF gave $\mathbf{4 b}$, which consists of a mixture of compounds with cis and trans double bonds, in $98 \%$ overall yield $\left(\mathrm{mp}>330^{\circ} \mathrm{C}\right.$ ). The propenyl moieties of compound $4 \mathrm{~b}$ could be ozonized in $\mathrm{CHCl}_{3}$ at $-20^{\circ} \mathrm{C}$ affording 11,23 -diformyl-26,28-dimethoxycalix[4]arene $4 \mathrm{c}$ in $95 \%$ yield ${ }^{13}$. It proved to be important to control the amount of ozone added, because otherwise overoxidation occurred. Compound $4 \mathrm{c}$ is an important synthon because the aldehyde groups will give access to a number of disubstituted calix[4]arenes. For example $4 \mathbf{c}$ could be converted into the 11,23-bis(chloromethyl)-26,28-dimethoxycalix[4]arene $4 e$ by reduction with $\mathrm{BH}_{3} / \mathrm{THF}$ at $-40{ }^{\circ} \mathrm{C}$ to give $4 \mathrm{~d}\left[\mathrm{mp}>330{ }^{\circ} \mathrm{C} ;{ }^{1} \mathrm{H}\right.$ NMR: $\delta 5.49$ (d, $\mathrm{CH}_{2} \mathrm{OH}$ )], followed by reaction of $4 d$ with $\mathrm{SOCl}_{2}$ in $\mathrm{CHCl}_{3}$ in an overall yield of $90 \%$ [4e: ${ }^{1} \mathrm{H} \mathrm{NMR:} \delta 4.52$ (s, $\left.\mathrm{CH}_{2} \mathrm{Cl}\right)$ ]. When the phenolic $\mathrm{OH}$ groups of $4 \mathrm{c}$ were methylated $\left(\mathrm{Mel} / \mathrm{K}_{2} \mathrm{CO}_{3} / \mathrm{CH}_{3} \mathrm{CN}\right.$ ) to give $7 \mathrm{a}\left(\mathrm{mp} 80-82^{\circ} \mathrm{C}\right.$ ) quantitatively, compounds $7 \mathrm{~b}\left(\mathrm{mp} 68-79{ }^{\circ} \mathrm{C}\right.$ ) and $7 \mathrm{c}$ (overall yield from $4 \mathrm{c} 90 \%$; $\mathrm{mp} 202-203{ }^{\circ} \mathrm{C}$ ) could be prepared analogously to the synthesis of $4 \mathbf{d}$ and $4 \mathrm{e}$. Compared with the 11,23-bis(chloromethyl)calix[4]arene 
4e, the O-alkylated compound $7 \mathrm{c}$ is more stable and could be purified by column chromatography.

Transformation of functionality from the lower to the upper rim could also be achieved starting from 26,28-bis(benzyloxy)calix[4]arene $2 \mathbf{c}$. The advantage of $\mathbf{2 c}$ is that the benzyl moieties can be removed selectively. Analogously to the synthesis of $4 \mathbf{4 a}, 11,23$-diallyl-26,28-bis(benzyloxy)calix[4]arene 5 ( $\mathrm{mp} 75-76^{\circ} \mathrm{C}$ ) was prepared by Claisen rearrangement of 25,27-bis(allyloxy)-26,28-bis(benzyloxy)calix[4]arene $3 b^{14}$ in $40 \%$ overall yield. The poor yield is probably due to the strenuous reaction conditions (refluxing N,Ndimethylaniline), e.g. causing debenzylation. From the reaction mixture 5,17-diallylcalix[4]arene 6 was isolated in $7 \%$ yield (mp $85-87.5^{\circ} \mathrm{C}$ ). This product also could be prepared in quantitative yield by Claisen rearrangement of 26,28-bis(allyloxy)calix [4]arene $\mathbf{2 b}$.

The second approach for the selective functionalization of the upper rim comprises selective reactions on the para positions of the phenol rings of the dialkylated calix[4]arenes. In literature examples are known from phenols that undergo much more readily Lewis acid catalyzed dealkylation than phenol ethers ${ }^{15}$. Reaction of 26,28-diethoxy-p-tert-butylcalix[4]arene 2d with two equivalents of $\mathrm{AlCl}_{3}$ in toluene at ambient temperature yielded $60 \%$ of 8 , which shows in the ${ }^{1} \mathrm{H}$ NMR spectrum only one singlet for the tert-butyl groups at $\delta 1.06^{11}$. In 8 the para positions of the phenol rings are now available for further substitution, while the remaining two para positions are blocked. When 8 was refluxed with excess of dimethylamine and formaldehyde in dioxane/water for $24 \mathrm{hrs}$, resp. $55 \%$ and $19 \%{ }^{16}$ of the 11-mono- and 11,23-bis[(dimethylamino)methyl]-5,17-di-tert-butyl26,28-diethoxycalix[4]arenes $9 \mathrm{a}$ and $9 \mathrm{~b}$ could be isolated. Compound 9a [ ${ }^{1} \mathrm{H}$ NMR: $87.1-6.5(\mathrm{~m}), 6.90(\mathrm{~s}), 6.78$ $(\mathrm{s}, \mathrm{ArH})]$ could be converted into 9b ${ }^{1} \mathrm{H}$ NMR: $\left.\delta 6.90(\mathrm{~s}), 6.78(\mathrm{~s}, \mathrm{ArH})\right]$ by further treatment with dimethylamine/formaldehyde.

In the third approach we could show that selective blocking of two para positions is not always necessary. Bromination of 26,28-dimethoxycalix[4] arene $2 \mathrm{a}$ with $\mathrm{Br}_{2}$ in $\mathrm{CHCl}_{3}$ at room temperature gave 11,23-dibromo26,28-dimethoxycalix[4]arene $10\left(\mathrm{mp}>330^{\circ} \mathrm{C}\right.$ ) in $82 \%$ yield. Nitration of 2a with two equivalents of conc. $\mathrm{HNO}_{3}$ in $\mathrm{CH}_{2} \mathrm{Cl}_{2} / \mathrm{AcOH}$ at room temperature afforded 26,28-dimethoxy-11,23-dinitrocalix[4] arene $11(57 \%, \mathrm{mp}$ $>330^{\circ} \mathrm{C}$ ). In both cases the substitution exclusively took place at the para positions of the phenol rings, as was

Figure 1. View of 26,28-dimethoxy11,23-dinitrocalix/4]arene

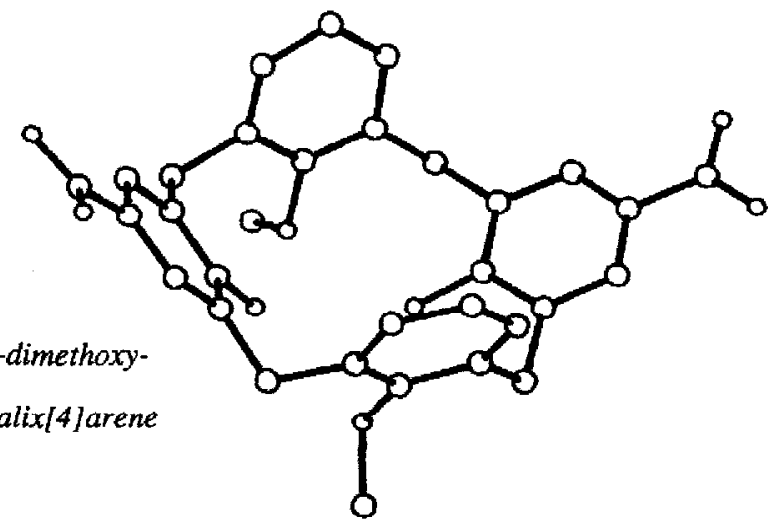

demonstrated for 11 by X-ray analysis. Compound 11 forms suitable crystals from chloroform, which are very unstable out of solution, loosing solvent molecules immediately. The X-ray structure ${ }^{17,18}$ (Fig. 1) shows the macrocycle in a flattened cone conformation. It is also possible to perform a selective Mannich reaction. When 2a was refluxed with excess of dimethylamine and formaldehyde in dioxane/water for 3 days, 
26,28-dimethoxy-11,23-bis[(dimethylamino)methyl]calix[4]arene 12 could be isolated in $91 \%$ yield ( $\mathrm{mp}>330$ ${ }^{\circ} \mathrm{C}$ ). The ${ }^{1} \mathrm{H}$ NMR spectrum shows a cone conformation with $\mathrm{ArCH}_{2} \mathrm{~N}$ as a singlet at $\delta 3.30^{19}$.

We can conclude that selectively diametrically disubstituted calix[4]arenes can be prepared in good yields and we are currently studying the introduction of various functional groups at the upper rim of the calix[4]arene moiety.

Acknowledgement. This investigation was supported by the Netherlands Foundation for Chemical Research (SON) with financial aid from the Netherlands Organization for Scientific Research (NWO).

\section{References and notes.}

1. Gutsche, C.D. Prog. Macrocyclic Chem. 3 (Synth. Macrocycles) 1987, 93-165.

2. Andreetti, G.D.; Ungaro, R.; Pochini, A. J. Chem. Soc., Chem. Commun. 1979, 1005.

3. Gutsche, C.D.; Iqbal, M.; Alam, I. J. Am. Chem. Soc. 1987, 109, 4314.

4. Ungaro, R.; Pochini, A.; Andreetti, G.D. J. Inclusion Phenom. 1984, 2, 199.

5. Reinhoudt, D.N.; Dijkstra, P.J.; in 't Veld, P.J.A.; Bugge, K.E.; Harkema, S.; Ungaro, R.; Ghidini, E. $J$. Am. Chem. Soc. $1987,109,4761$.

6. Gutsche, C.D.; Levine, J.A.; Sujeeth, P.K. J. Org. Chem. 1985, 50, 5802.

7. Only one example is known of the introduction of one allyl group at the upper rim. (Gutsche, C.D.; Lin, L.-G. Tetrahedron 1986, 42, 1633.)

8. Goldmann, H.; Vogt, W.; Paulus, E.; Böhmer, V. J. Am. Chem. Soc. 1988, 110, 6811,

9. Gutsche, C.D.; Dhawan, B.; Levine, J.A.; No, K.H.; Bauer, L.J. Tetrahedron 1983, 39, 409.

10. All compounds in this paper showed satisfactory spectral data, including matched mass spectra, and elemental analyses $(\mathrm{C}, \mathrm{H}, \mathrm{N} \pm 0.4 \%)$.

11. 26,28-Diethoxy-p-tert-butylcalix[4]arene $2 \mathbf{d}$ could be prepared from $\mathbf{1 b}$ using 4 equivalents of ethyl tosylate and 20 equivalents of $\mathrm{K}_{2} \mathrm{CO}_{3}$ in refluxing acetone $\left(60 \%\right.$ yield, the ${ }^{1} \mathrm{H}$ NMR spectrum shows two singlets for the tert-butyl groups at $\delta 1.01$ and 1.12).

12. Very recently McKervey published similar results with other alkylating agents e.g. $\mathrm{BrCH}_{2} \mathrm{CO}_{2}$ Et. (Collins, E.M.; McKervey, M.A.; Harris, S.J. J. Chem. Soc., Perkin Trans. I 1989, 372).

13. 11,23-Diformyl-26,28-dimethoxycalix[4]arene $4 \mathrm{c}: \mathrm{mp}>315^{\circ} \mathrm{C} ;{ }^{1} \mathrm{H}$ NMR $\delta 9.81(\mathrm{~s}, 2 \mathrm{H}, \mathrm{CH}=\mathrm{O}$ ), 8.66 (s, $2 \mathrm{H}, \mathrm{OH}), 7.65(\mathrm{~s}, 4 \mathrm{H}, \mathrm{ArH}), 7.1-6.6(\mathrm{~m}, 6 \mathrm{H}, \mathrm{ArH}), 4.32$ and $3.52\left(\mathrm{ABq}, 8 \mathrm{H}, J=13.4 \mathrm{~Hz}, \mathrm{ArCH}_{2} \mathrm{Ar}\right), 4.02$ $\left(\mathrm{s}, 6 \mathrm{H}, \mathrm{OCH}_{3}\right)$; IR(KBr) $1685(\mathrm{C}=\mathrm{O}) \mathrm{cm}^{-1}$; mass spectrum, $\mathrm{m} / \mathrm{e} 508.1930\left(\mathrm{M}^{+}\right.$, calcd 508.1886$)$. Anal. Calcd for $\mathrm{C}_{32} \mathrm{H}_{28} \mathrm{O}_{6} .0 .6$ EtOAc: $\mathrm{C}, 73.59 ; \mathrm{H}, 5.89$. Found: $\mathrm{C}, 73.32 ; \mathrm{H}, 5.64$.

14. According to HPLC $3 \mathrm{~b}$ contains several conformers.

15. See for instance: Tashiro, M.; Koya, K.; Yamato, T. J, Am. Chem. Soc. 1982, 104, 3707.

16. Yields are calculated from recovered starting material.

17. Crystal data: $\mathrm{C}_{30} \mathrm{H}_{26} \mathrm{~N}_{2} \mathrm{O}_{8} .1 .5 \mathrm{CHCl}_{3}$, monoclinic, space group $\mathrm{P} 2{ }_{1} / \mathrm{c}, \mathrm{a}=10.143(8), \mathrm{b}=22.358(15)$, $c=14.756(13) \AA, \beta=102.94(9)^{\circ}, V=3261(9) \AA^{3}, d_{c}=1.47 \mathrm{~g} / \mathrm{cm}^{3}, \mathrm{Z}=4, \mu(\mathrm{MoK} \alpha)=4.56 \mathrm{~cm}^{-1}, \mathrm{~T}=293 \mathrm{~K}$. 3044 reflections measured in $\omega / 2 \theta$ scan mode; $2.5^{\circ}<\theta<20^{\circ}$. Solution by MULTAN. (Germain, G.; Main, P.; Woolfson, M.M. Acta Crystallogr., Sect. B. 1970, 26, 274. Main, P. "Computing in Crystallography"; Schenk, H., Ed., Delft University Press; The Netherlands, 1978). Because the crystal was very unstable out of solution, loosing $\mathrm{CHCl}_{3}$ immediately, it was mounted in a capillary, $\varnothing=0.3 \mathrm{~mm}$, filled with $\mathrm{CHCl}_{3}$. One $\mathrm{CHCl}_{3}$ molecule was found in a general position, the other one on the $2 \mathrm{~d}$ position in a disordered manner. Refinement with 1916 reflections $\left[\mathrm{F}_{0}^{2}>2.5 \sigma\left(\mathrm{F}_{0}^{2}\right)\right]$; parameters: scale factor, positions and anisotropic temperature factors of all atoms (except the $\mathrm{CHCl}_{3}$ carbon atom on the $2 \mathrm{~d}$ position). No attempt was made to locate hydrogens due to the partial disorder of the $\mathrm{CHCl}_{3} . \mathrm{R}=8.8 \%, \mathrm{R}_{\mathrm{w}}=10.0 \%[\omega=$ $4 \mathrm{~F}_{\mathrm{o}}^{2} / \sigma\left(\mathrm{F}_{\mathrm{o}}^{2}\right)$ ] for 430 variables. All calculations were done using SDP.(Structure Determination Package, Frenz, B.A. and Associates., College Station, Texas, and Enraf Nonius, Delft, 1983.)

18. Atomic coordinates for this structure have been deposited with the Cambridge Crystallographic Data Centre. The coordinates can be obtained on request from The Director, Cambridge Crystallographic Data Centre, University Chemical Laboratory, Lensfield Road, Cambridge CB2 1EW, U.K..

Complete lists of positional parameters for all atoms and anisotropic thermal parameters for heavy atoms, and lists of bond lengths and bond angles have been deposited as Supplementary Material with the British Library Lending Division, Boston Spa, Werherby, West Yorks LS23 7BQ, U.K..

19. Under the reaction conditions used by Gutsche $2 a$ did not react. This suggests that calix[4]arene 1a is more reactive than dimethoxycalix [4]arene $2 \mathrm{a}$ because the phenols of la are more acidic. (Gutsche, C.D.; Nam, K.C. J. Am. Chem. Soc. 1988, 110,6153.) 